Revista Portuguesa de História

t. XXXIV (2000)

\title{
Coimbra e Santiago de Compostela: aspectos de um inter-relacionamento nos séculos medievos
}

SAUL ANTÓNIO GOMES

Universidade de Coimbra

1 - Nos tempos medievais nem as cidades nem os seus habitantes constituíam estruturas estáticas. As cidades, primeiramente, porque espaços que se expandiam pela topografia do lugar, crescendo o seu casario, multiplicando-se os fiéis e as igrejas paroquiais, estendendo-se as suas muralhas a novos circuitos ou aumentando o espaço de habitação fora de muros, alargando-se os bairros de mesteirais pelas imediações da cidade encastelada, na procura dos veios de água ou de outras condições naturais que lhes permitissem a força motriz para movimentar azenhas e moinhos, pisões e engenhos, ou o escoamento dos resquícios poluentes provocados pelas respectivas actividades profissionais. Os homens, seguidamente, porque chamados ao dinamismo da vida social e económica do meio em que residiam, dedicados, uns, ao trabalho manual, ao comércio, mesmo a actividades de carácter mais agrário que 


\section{Saul António Gomes}

faziam, naturalmente, parte da paisagem e do labor citadinos, outros, ainda, ao exercício e controle da administração pública local, garantindo privilégios, direitos e regalias, aplicando leis e fazendojustiça consoante os foros e costumes aplicáveis'.

Cidades antigas ou urbes novas, fortificadas ou abertas, por todas elas circulavam pessoas, a todas se acolhiam viajantes e por todas passavam os senhores da guerra, cruzados ou mercenários, ou os homens vilãos, homens de paz dedicados ao trabalho manual, ao comércio ou mesmo a profissões de foro mais liberal. Nas cidades medievas, igualmente, se cruzavam numerosos peregrinos, lembrando que a vida religiosa, a espiritualidade, a Fé eram factores de importância maior no quotidiano do Homem.

$\mathrm{Na}$ dinâmica que caracterizava as urbes peninsulares dos séculos medievais, as cidades de Coimbra, sede episcopal que se podia ufanar dos seus pergaminhos ancestrais como centro de enraizamento do Cristianismo no território centro-ocidental da Ibéria, e de Compostela, mais recente do que aquela, posto que rapidamente afirmada como pólo espiritual vocacionado para centralizar a Cristandade ocidental, desempenharam vocações diferenciadas, marcadas pela distância geográfica, como se sabe, mas aproximadas pelos homens e pelos contactos interrelacionais que estes souberam e necessitaram de desenvolver.

Foi já assinalada a importância, por exemplo, que os modelos de edificação arquitectónica de aparato seguidos em ambiente compostolense adquiririam noutras cidades vizinhas, especialmente em urbes com a dignidade episcopal, onde se detectam opções de imitação (tanto quanto

A bibliografia sobre as cidades medievais portuguesas é já muito abundante. Remetemos, apenas, para a síntese proposta em Nova História de Portugal. (Dir. A. H. Oliveira Marques e Joel Serrão),Vol. III. Portugal em Definição de Fronteiras. Do Condado Portucalense à Crise do Século XIV, (Coord. Maria Helena da Cruz Coelho c Armando Luís de Carvalho Homem), Lisboa, Presença, 1996, pp. 386-400. 
de eventual concorrência...) do modelo construtivo jacobeu ${ }^{2}$. Em Portugal, decerto, não poderiam as cidades episcopais deixar de se sentirem motivadas pelo exemplo e protagonismo compostolenses.

De Braga, como se sabe, poderemos escrever que a política episcopal seguida em ordem a afirmá-la como um outro centro cristão possuidor de relíquias de exemplares mártires e bons santos, cedo sofreria rudes golpes pela oposição e acção depredatória do arcebispo compostelano. De Coimbra, no entanto, ainda que com maior discrição, poderemos escrever que os seus bispos (destacando-se, entre eles, D. Miguel Pais Salomão, no episcopado coimbrão nos anos de 1159 e 1162-1176) e demais colégio sacerdotal, especialmente depois da entronização de D. Afonso Henriques, não deixaram também de procurar enriquecer a sede catedralícia, como outros institutos religiosos, mormente os Mosteiros desta cidade, com interessantes espécimes de relíquias recolhidas em certamente aparatosos e impressivos relicários. De Lisboa, cumpre sublinhar a importância e a tradição local do culto dos santos mártires hispânicos, afirmando-se sobre todos o caso de S. Vicente ${ }^{3}$.

Estas cidades episcopais, como outras no território português, contudo, manteriam, no fenómeno da devoçãojacobeia, um papel transitório, mais de espaços de passagem e acolhimento de curta duração do que de pólos de recepção e permanência de peregrinos e devotos caminhantes. Não deixariam, contudo, de se afirmar, também elas, como espaços de oferta devocional merecedores das visitas, das orações e das esmolas dos fiés ${ }^{4}$.

${ }^{2}$ Manuel Luís REAL, "O projecto da Catedral de Braga, nos finais do século XI, e as origens do românico português", Congresso Internacional: IX Centenário da Dedicação da Sé de Braga - Actas, Braga, 1990, Vol. I, pp. 435-489.

${ }^{3}$ Cf. Aires A. NASCIMENTO e Saul António GOMES, 5. Vicente de Lisboa e seus milagres medievais, Lisboa, Didaskalia, 1988.

‘ Seja-nos permitido remeter, sobre estes temas, para as páginas que publicámos com o título! "A Religião dos clérigos: vivências espirituais, elaboração doutrinal e transmissão cultural". História Religiosa de Portuga]. Vol. I, Formação e Limites da 


\section{$\underline{\text { Saul António Gomes }}$}

2 - As relações entre Coimbra e Santiago de Compostela remontam à mais recuada Idade Média. No estado actual dos conhecimentos históricos sobre este assunto, podemos escrever que, na região coimbrã, se venerou desde muito cedo o Apóstolo S. Tiago Maior. Na base dessa devoção, para além das próprias tradições cultuais hispano-cristãs conimbricenses ${ }^{5}$, poderá estar a política régia de D. Afonso III, de Oviedo, devidamente sintonizada, decerto, com objectivos religiosos caros à pastoral do episcopado norte-hispânico desse tempo, de promoção do Santuário Compostolense por toda a Hispania cristã.

Deveremos considerar, também, o especial interesse que Afonso III, o Magno, colocou na edificação do grande Santuário galego, especialmente a partir de finais do século IX, prova, de forma inquestionável, a importância que o culto a S. Tiago Maior revestia no conspecto devocional desse mesmo monarca e de toda a sua corte. À intercessão de S. Tiago atribuía Afonso III as muitas vitórias que obtivera sobre o poderio sarraceno, nomeadamente as conquistas de cidades como Braga, Porto. Idanha, Viseu e Coimbra. Pela posse vitoriosa desta, aliás, combateria o conde Hermenegildo Mendes em nome deste monarca, em 878, permanecendo Coimbra sob domínio cristão até $987^{6}$. Aceitar-se-á, deste modo, que Afonso III tenha desejado propalar o culto jacobeu por terras mondeguinas, posto que nelas haja encontrado comunidades de moçára-

Cristandade (Dir. Carlos Moreira Azevedo), Lisboa, Círculo de Leitores, 2000, pp. 339-421, maxime 388-391.

'DAVID, Pierre, Études Historiques sur la Galice et le Portugal du VIe au Xlle Siècle, Lisboa, Livraria Portugália, 1947, pp. 185-256.

'Vide Crónica Geral de Espanha de 1344 (ed. crítica por Luís Filipe Lindley CINTRA), Vol. II, Lisboa, 1984, pp.450-459; Pierre DAVID, "Coimbre", Dictionnaire d'Histoire et de Géographie Ecclésiastique, T. 13, Paris, 1956, cols. 204-211; Avelino de Jesus da COSTA, "Coimbra", in Verbo - Enciclopédia Luso-Brasileira de Cultura, Vol. 5, Lisboa, Verbo, 1967, cols., 862-863; Idem, "Coimbra, Bispado de", Dicionário de História de Portugal (Dir. Joel Serrão), Vol II, Livraria Figueirinhas, Porto, s. d., pp. 93-94. 
bes em cujos registos culturais e memoriais se verificariajá uma devoção ancestral àquele Apóstolo ou, no mínimo, uma predisposição para a sua integração no santoral comemorativo local.

Tomada para o poderio dos monarcas asturianos em 878, como escrevemos, Coimbra tornar-se-á palco onde se desenvolverão acções tendentes ao estabelecimento não só de um novo poder condal, protagonizado pela família de D. Hemenegildo Guterres, como, sobremodo, ao enraizamento de medidas em ordem ao fortalecimento da unidade da comunidade cristã. Unidade que encontrava na devoção jacobeia, sem dúvida, um bom incentivo e um novo impulso de consolidação de uma identidade religiosa e cultural. Compreende-se, assim, que D. Afonso III estendesse os interesses patrimoniais de Santiago de Compostela à região mondeguina - como, também, a outras regiões do norte portucalense - e, ainda, que se incentive a propalação de ermidas e templos dedicados à memória de S. Tiago.

Em 17 de Agosto de 883, aquele Monarca doava à igreja de Santiago de Compostela a propriedade do acistério de S. Salvador de Montélios?. Em 25 de Setembro desse mesmo ano, como, mais tarde, se reiteraria em nova carta de 30 de Dezembro de 898 ou 899, D. Afonso III dotava a mencionada igreja compostolense com as uillae de Vilela, de Trouxemil e a terça parte da uilla de Travaçô, entre Águeda e Vouga, no território de Coimbra ${ }^{8}$. Invocando expressamente S. Tiago Maior como seu

"(...) Monasterium quod fuit edificatum a beato Dei uiro domno Frutuoso, cuius meritum et uitam sacra scriptura testatur. Quod monasterium situm est in locum Montelios inter monasterium Dumiense atque suburbio Bracharense, quod ab antico cognoscitur fore in Sancti Saluatoris fundatus honore." (Tumbo A de la Catedral de Santiago. (Estudio y Edición de Manuel LUCAS ALVAREZ), Santiago, Cabildo de la S. A. M. I. Catedral - Seminario de Estudios Galegos, 1998, doc. 10, pp. 61-62).

s"(...) Villas in suburbio Conimbriense, quas nuper Dominus de manu gentilium abstulit et, sancta uestra intercessione, dicioni nostre subdidit. Id est: Uilla in ripa de fluuio Uiaster cum ecclesia uocabulo Sancto Martini, et uilla Crescemiri, siue et iuxta fluuio uilla cum ecclesia Sancti Laurenti et terciampartem de uilla Trauazolum inter Agatam et Uaugam." (Tumbo A de la Catedral de Santiago, doe. 17, p. 71; Livro Preto, doc. 12). 
padroeiro e protector, para sua honra e perpétua glória", o Monarca justificou o acto como sendo "pro subsidio pauperum et susceptione peregrinorum siue aduenum"

Esta doação seria renovada por Fernando Magno, decerto em $1063^{10}$, ao bispo D. Crescónio e ainda a "omnibus ecclesie sancti Iacobi apostoli canonicis", afirmação que interpretamos como respeitante ao antiste e Cabido diocesanos de Compostela". Com ela, eventualmente, D. Fernando Magno manifestava premonitoriamente a sua intenção em reconquistar Coimbra para o poderio cristão, tal como, meses mais tarde, viria a suceder após um longo assédio do exército do monarca asturoleonês à cidade do Mondego ${ }^{12}$.

Em nenhum destes documentos, contudo, se refere a existência de alguma igreja dedicada a S. Tiago, posto que uma das "uillae" indicadas sejajustamente a de Trouxemil (< "Creisemiri") que encontraremos mais tarde como sede paroquial sob a invocação jacobeia. Mas a devoção a Santiago, entretanto, alastraria na região coimbrã. Efectivamente, sabemos, por um documento datado do ano de 937, que na povoação de Souselas, havia já ermida dedicada a este Santo, tendo sido, nessa data, os seus direitos testados ao Mosteiro de S. Mamede de Lorvão ${ }^{13}$.

' "Domino sancto, glorioso ac post Deum fortissimo patrono Iacobo apostolo, cuius corpus tumulatum esse dignoscitur sub Arcis marmoricis, prouincia Gallecie. Ego Adefonsus princeps, in Domini nostri lhesu Christi et uestre perpetue glorie honore (...)". (Tumbo A de la Catedral de Santiago, cit., doc. 17, pp. 70-71).

${ }^{10}$ Livro Preto da Se de Coimbra, (cura Torquato de Sousa SOARES e A. G. Rocha MADAHIL (vol. 1); Avelino de Jesus da COSTA, Leontina VENTURA e Maria Teresa Nobre VELOSO (vols. 2 e 3)), Coimbra, Arquivo da Universidade,1977; nova edicão Livro Preto. Cartulário da Se de Coimbra (cura Manuel Augusto RODRIGUES e Avelino de Jesus da COSTA), Coimbra, Arquivo da Universidade de Coimbra, 1999, $\mathbf{n}^{\circ}$ 13, p. 22.

" Livro Preto da Se de Coimbra, n's 12 e 13.

${ }^{12}$ Cf. João Pedro RIBEIRO, "Sobre a epoca da conquista de Coimbra no reinado de D. Fernando I de Leão", Dissertações Chronologicas e Criticas sobre a Historia $e$ Jurisprudencia Ecclesiastica e Civil de Portugal, Tomo I, Lisboa, 1860, pp. 1-48.

${ }^{13}$ Arquivo Nacional da Torre do Tombo (=TT) — Liber Testamentorum de Lorvão, fl. $8 \mathrm{v}^{\circ}$; Portugaliae Monumenta Historica - Diplomata et Chartae, Lisboa, Vol. I,1867. doc. XLIV, p. 27. 
Poderemos afirmar que quer com Afonso III, quer com a confirmação posterior de Fernando Magno, nos encontramos perante actos cuja principal consequência terá sido a de reforçar os interesses dominiais do Santuário jacobita em pingues territórios situados entre as linhas dos rios Douro e Mondego. Isso revelará uma estratégia de valorização e de divulgação daquele centro devocional religioso galego, tanto quanto uma atitude ideológica especificamente filiada na ambiência de Reconquista dos territórios debaixo do poder sarraceno, a qual encontraria na valoração religiosa do culto jacobeu um dos mais estimulantes e principais esteios da crença e das estruturas mentais que caracterizavam, justificavam e motivavam os exércitos cristãos da Península.

3 - A devoção entre os cristãos conimbricenses a S. Tiago Maior comprova-se categoricamente, como começámos por escrever, na primeira metade do século $\mathrm{X}$, com a referência documental à igreja de $\mathrm{S}$. Tiago de Souselas, do ano 937.

Esta situação parece-nos de grande interesse porque evoca um contexto histórico que deve ser algo distinto das ligações que, mais tardiamente, se detectam entre paróquias e diocesanos das mais diferentes regiões peninsulares com o grande Santuário galego. Podemos escrever, assim, que já na primeira metade do século X, e em pleno domínio muçulmano de Aeminium, os moçárabes conimbricenses mantinham viva a devoção por Santiago Maior.

Isto numa época em que a propalação internacional do Santuário jacobeu se encontrava ainda numa fase de afirmação e crescimento. Podemos pensar, assim sendo, que se tratará de um caso de sobrevivência hispânica hagiográfica memorial sobre Santiago Maior. Os moçárabes coimbrãos cultuariam Santiago Maior, aliás, em sintonia com o conspecto socio-religioso global que caracterizava os territórios situados entre Minho e Mondego, onde o santoral hispânico assumia características 


\section{Saul António Gomes}

individualizantes.

Segundo Pierre David, a partir do século VII, no território ocidental hispânico, generalizou-se o fenómeno da atribuição de oragos titulares às igrejas e ermidas. Na Galiza, como no espaço situado a norte do Mondego, vulgarizaram-se as intitulações sob o epíteto de S. Salvador. Nalgumas igrejas foi corrente, ainda, a atribuição de padroeiros secundários. Citemos os casos do Mosteiro da Vacariça cuja titulatura completa começava por S. Salvador, sendo no entanto mais conhecido pela intitulação de S. Vicente, e do Mosteiro de S. Mamede de Lorvão designado na documentação, ocasionalmente, por S. Pelágio. Isto para a primeira metade do século $\mathrm{X}^{14}$.

Os documentos dos séculos XI e XII demonstram a evolução do santoral hipano-coimbrão no sentido da atribuição em maior número das invocações eclesiais â Mãe de Deus, a $\mathrm{St}^{\mathrm{a}}$ Maria, em cujas imediações se situava normalmente um baptistério dedicado a S. João Baptista (o exemplo da cidade de Coimbra - Sé e, nas imediações, S. João da Almedina - é o mais preclaro). Depois, as modas distribuíam-se pelos oragos dos Apóstolos S. Pedro e S. Paulo, seguidos por S. Tiago Maior que aparece com 25 ocorrências para o território de entre Mondego e Minho. Sucediam-lhes oragos com menor expressão.

$\mathrm{Na}$ cidade de Coimbra encontramos ainda, para o século X, igrejas e ermidas dedicadas a S. Bartolomeu, S. João Baptista, S. Cristóvão, St ${ }^{a}$ Cristina, e $\mathrm{St}^{\mathrm{a}}$ Eufemia, a que se juntarão, em época mais tardia, outras ermidas paroquiais e colegiais ${ }^{15}$.

${ }^{14}$ Pierre DAVID, " Le Sanctoral Hispanique et les Patrons d'Églises Entre le Minho et le Mondego du IXe au XIe Siècle", Études Historiques sur la Galice et le Portugal du VIe au XIIe Siècle, Lisboa, Institut Français au Portugal, 1947, pp. 185-236, maxime 226-236.

${ }^{15}$ Nomeadamente as colegiadas de S. Salvador, S. Pedro, St ${ }^{\mathbf{a}}$ Justa e Santiago, a paroquial de S. João Evangelista (anexa ao Mosteiro de Santa Cruz), para além das igrejas de ordens regulares levantadas na cidade ou na sua periferia. Vd. António de 
4 - Coimbra acompanhava, desde cedo, como vimos, a afirmação, que poderemos classificar institucional, do Santuário Iriense como epicentro hispânico e europeu do culto ao Apóstolo S. Tiago. Não admira, assim sendo, que a cidade se torne num importante pólo nos itinerários da peregrinação jacobeia. Porque cidade privilegiada pela sua localização geográfica no centro do território português, próxima da orla marítima e servida de uma boa via fluvial, de facto, Coimbra afirmar-se-á durante os séculos medievais como pólo privilegiado no estabelecimento dos contactos e das viagens dos homens entre o Sul e o Norte. Viagens em que se avolumava, pelo seu significado particular, o trilho dos peregrinos de Santiago de Compostela ${ }^{16}$.

Uma descrição datada de 1153, devida ao muçulmano Xerif Aledris, por exemplo, enuncia o valor estratégico centralizador de Coimbra, ao mesmo tempo que aponta a cidade como lugar importante do caminho da peregrinação jacobeia:

"Confina Shintera (Sintra) e Lisboa de Veled Esbania com Medina Colamria (Coimbra); e entre Colamria e Shenterin (Santarém) na parte meridional três jornadas; e entre Colamria e o mar na parte ocidental doze milhas, e aqui desemboca o rio chamado Mondin (Mondego); e sobre o desaguamento no mar o castelo de Montemor, e está sobre a margem do mar; e há o caminho de Colamria a S. Jacob. (...)"

VASCONCELOS, A Sé-Velha de Coimbra, Vol. 1,2 ed., 1992, pp. 92-107; Pierre DAVID, A Sé Velha de Coimbra, Porto, Portucalense Ed., 1943, passim.

${ }^{16}$ Aspectos já evidenciados nos estudos de Maria Helena da Cruz COELHO, mormente nas obras e estudos; O Baixo Mondego nos Finais da Idade Média (Estudo de História Rural), Coimbra, Faculdade de Letras, 1983, vol. I, pp. 1-5 et passim; Eadem, Coimbra Trecentista: A Cidade e o Estudo, separata de Biblos, Coimbra, Vol. 68 (1992); "A Feira de Coimbra no Contexto das Feiras Medievais Portuguesas", Ócio e Negócio em Tempos Medievais, Coimbra, Inatel, 1998, pp. 1 -45, maxime 6-7. Importa, ainda, o texto de Leontina VENTURA, "A muralha coimbrã na documentação medieval". Actas das I Jornadas do Grupo de Arqueologia e Arte do Centro, Coimbra, GAAC, 1979, pp. 43-56.

Livro Preto..., p. LXXIX. 


\section{Saul António Gomes}

Também o celebrado geógrafo Edrici, por essa mesma época, alude a Coimbra como cidade polarizadora de circuitos terrestres e fluviais. Destacando as ligações entre Coimbra e Santarém, ou seja, com o territórios taganos, Edrici sublinhará com particular acuidade a importância da cidade do Mondego no caminho de Santiago. Pela via marítima, os viajantes passariam pelas embocaduras dos rios Vouga, Douro, Minho e Taron; pela via terrestre, os peregrinos percorreriam um itinerário sempre próximo da orla costeira:

"O caminho de Coimbra a Santiago por terra é o seguinte: de Coimbra à alcaria de Agueda há um dia de viagem e daí à alcaria de Oliveira [de Azeméis] outro dia de viagem e outro, ainda, dela ao princípio da Terra de Portugal, cuja largura o caminho atravessa num dia. Nela fica a alcaria nova de Gaia, junto do rio Douro, isto é, o rio de Zamora. Este rio passa-se ali em barcos próprios para a travessia. Desta alcaria ao castelo de -, no rio Minho, há 60 milhas, ou seja, dois dias de viagem."

5 - Ao contexto expansivo da Reconquista se deverá atribuir uma posterior generalização do culto jacobeu por toda a Península, e mesmo a integração da expressão plural que esta devoção assume na Diocese coimbrã, após a centúria undecentista, nos circuitos de peregrinações internacionais a Compostela. Contexto que pressupõe a expansão por territórios peninsulares da reforma romano-gregoriana protoganizada pelo clero secular, tanto quanto pela acção eficaz dos cluniacenses e demais ordens monásticas. A evolução e o triunfo internacional da peregrinação jacobeia foi, ainda e necessariamente, uma das consequências do novo olhar político e pastoral que Roma deita sobre a Península Ibérica desde finais do século $\mathrm{XI}^{19}$.

${ }^{18}$ António Borges COELHO, Portugal na Espanha Árabe. Vol. 1. Geografia e Cultura, Lisboa, Caminho, 1989, pp. 71-72.

${ }^{19}$ Vide Carl ERDMANN, O Papado e Portugal no Primeiro Século da História Portuguesa, Coimbra, Inst. Alemão da Universidade de Coimbra e Coimbra Editora, 1935, pp. 5 e segs. 
É neste contexto, como se sabe, que surge a lenda de Santiago cavaleiro como é narrada no Codex Calixtinus (2, 19), segundo a qual, nas vésperas da conquista de Coimbra por Fernando Magno, em 9 de Julho de 1064, um bispo grego de nome Estêvão teria sido repreendido pelo próprio Santo. Narra essa lenda, que o erudito bispo Estêvão, acompanhando os exércitos de Fernando Magno, admoestou uns fiéis que imprecavam o Santo como "Santiago, bom cavaleiro", pois que, insistia o prelado, este Apóstolo era pescador e não cavaleiro. O estatuto mesteiral de pescador parece não ter agradado, igualmente, ao próprio S. Tiago que, logo na noite seguinte, apareceria ao prelado e o advertiria severamente dizendo: "Estêvão, filho de Deus, que quiseste que me chamassem não cavaleiro mas tão só pescador, eis que apareço a ti para te advertir que não voltes a duvidar que sou cavaleiro e campeão de Deus, e que vou à frente dos cristãos na sua luta contra os sarracenos."

Esta lenda sobreviverá no território nacional, coligindo-se, por exemplo, nas Vidas e Paixões dos Apóstolos ${ }^{20}$ Estabeleceram-se, contudo, outras versões originais com base naquela, sobretudo nos círculos cultos da Ordem de Santiago, como se prova por uma sua lição fixada no Livro dos Copos, composto cerca de 1484, sob a pena de Alvaro Dias de Frielas, escrivão do cartório daquela Ordem Militar. Nesta versão, contudo, a personagem central da história é um bispo eleito de Coimbra, remetendo-se a acção para o tempo de D. Afonso IV (1325-1357) ${ }^{21}$.

${ }^{20}$ Vidas e Paixões dos Apóstolos (ed. por Isabel Villares CEPEDA), Lisboa, INIC, 1982, Vol. I, pp. 331-333; Mário MARTINS, "Os Autos dos Apóstolos e o Livro de S. Tiago", Estudos de Literatura Medieval, Braga, Livraria Cruz, 1956, pp. 118-129; Luís Adão FOnSECA, " A Memória das Ordens Militares: o Livro dos Copos da Ordem de Santiago", As Ordens Militares em Portugal - Actas do $1^{\circ}$ Encontro Sobre Ordens Militares, Palmela, Câmara Municipal, 1991, p. 19.

${ }^{21} \mathrm{O}$ nome do monarca poderá resultar duma reminiscência arquétipo-textual ou oral da conquista de Coimbra em 878, por ordem de Afonso III das Astúrias? Vide Pedro de AZEVEDO, "Notícia d'Um Antigo Canto em Honra de S. Tiago", Revista Lusitana, Vol. 5, n $^{\circ}$ (1897), pp. 232-233; Manuel Cadafaz de MATOS, "O Culto Português de 


\section{Saul António Gomes}

A afirmação idealizada de um S. Tiago cavaleiro, na verdade, serviria mais adequadamente as preocupações devocionais das milícias guerreiras que acompanhavam os reis cristãos na reconquista da Hispania. Recordemos que, de facto, se encontram outros testemunhos literários do século XII, em que Santiago aparece como um guerreiro.

Assim acontece, por exemplo, num poema alusivo a uma vitória cristã sobre sarracenos, obtida em território português, de cerca 1110, Santiago é cantado justamente como "cavaleiro do invictíssimo imperador": "Quando ao Templo do Senhor em Jerusalém assediavam os inimigos / no céu aparece pelos ares um exército maravilhoso; / Com seus cavalos brancos, douradas armas, vestes refulgentes, / cavaleiros em defesa da justa Fé. / Assim, o poder do senhor e todo um exército celestial / prosseguem a batalha contra os inimigos da Fé. / Aí, sucedeu, onde muitos, os fiéis que o mereciam. / viram ao grande Santiago levando a sua bandeira." (Codex Calixtinus, 2, 18) $)^{22}$.

6 - Também ao bispo colimbriense D. Maurício Burdino (1099-1109) se atribuiu, no passado medieval, uma importante acção na promoção da identidade devocional por Santiago. Na verdade, a Historia Compostelana (1, 112), de cerca 1140, narra o episódio da descoberta do crânio de Santiago, achado, por revelação do Espírito Santo, pelo prelado de Coimbra quando se deslocou em peregrinação à Terra Santa (ca. 1104-1108). Regista essa lenda que o bispo conimbricense achou a cabeça do Santo numa igrejinha de Jerusalém, não hesitando em apoderar-se dela.

Sant' Iago de Compostela ao longo da Idade Média. Peregrinações de homenagem e louvor ao túmulo e à cidade do Apóstolo entre o Séc. XI e Séc. XV", Bibliotecas, Arquivos e Museus, Vol. I, T. II, Lisboa, 1985, pp. 521 -557, maxime 553-555; Luís Adão FONSECA, op. cit., pp. 18-20.

${ }^{22}$ MC. DIAZ Y DIAZ, "Santiago el Mayor a Traves de los Textos", Santiago, Camino de Europa. Culto y Cultura en la Peregrinación a Compostela, Santiago de Compostela, Xunta de Galicia et al, 1993, pp.3-15. 
Quando a transportava, no entanto, teria sido interpelado por um ermita que lhe declarou conhecer o furto que havia feito, mas que não se opunha a tal, uma vez que "é desejável que onde está o corpo do Apóstolo, estivesse também a sua cabeça". Por razões diversas que se prendem com a ascensão de Maurício Burdino à arquidiocese de Braga e, um pouco mais tarde, ao sólio pontifício como antipapa de nome Gregório VIII, a relíquia só seria depositada nas mãos do arcebispo compostelano, D. Gelmirez, em $1116^{23}$.

Estudos recentes demonstram que se trataria duma relíquia de outro Santo, justamente S. Tiago Alfeu, posto que o episódio tivesse sido classificado nos quadros hagiográficos medievo-compostelanos como relativo ao historial de Santiago Maior. Importa, no entanto, reflectir que esta lenda se deve inserir no contexto das lutas que opuseram os arcebispos de Braga e o Compostelano justamente pela definição dos direitos primaciais sobre dioceses, nomeadamente a de Coimbra, que era reclamada pelos arcebispos jacobeus ${ }^{24}$.

A ligação da diocese coimbrã à arquidiocese bracarense acabou por triunfar, não só por razões que derivavam dos contextos histórico-geográficos herdados da cartografia religioso-eclesial suévico-visigótica, como também pelos interesses políticos que respeitavam à coroa portucalense que, desde a primeira metade do século XII, desejava afirmar a independência do jovem Reino fazendo-a coincidir quase naturalmente com uma indispensável uniformização dos poderes eclesiásticos dentro do território português.

Como se sabe, Coimbra desempenhou um papel de grande relevo

${ }^{23}$ Citado por M. C. DIAZ Y DIAZ, op. cit., p. 6.

${ }^{24}$ Cf. José Marques, O Problema da Primazia Arquiepiscopal das Espanhas: Toledo ou Braga, separata de Stvdivm Dilectvm. Colectânea de Homenagem ao Prof. Doutor Justino Mendes de Almeida, Lisboa, Academia Portuguesa da História, 1999, pp. 199-222 . 
nesse processo da afirmação da independência nacional, como cidade de residência real e como centro de fronteira territorial onde se organizava a reconquista de territórios sud-mondeguinos e se desenvolviam fecundos círculos intelectuais monásticos e seculares de apoio ideológico à causa de D. Afonso Henriques ${ }^{25}$.

Neste sentido, recordemos que até praticamente inícios de Quatrocentos, a arquidiocese de Braga abrangia as dioceses galegas de Mondoñedo, Lugo, Astorga, Orense e Tui, e Braga, Porto, Viseu e Coimbra no território português. Por seu turno, a metrópole compostelana abrangia além da diocese iriense, as prelazias de Zamora, Salamanca, Ciudad Rodrigo, Ávila, Coria, Plasencia, Mérida e Badajoz, ficando-lhes adstritas, no espaço português, as dioceses de Lamego, Guarda/ Idanha, Lisboa e Évora ${ }^{26}$.

Este quadro geo-eclesial teve também alguns reflexos ao nível da estruturação das unidades administrativas dentro das Ordens religiosas regulares. Lembremos o caso significativo dos conventos franciscanos portugueses integrados na Província de Santiago até cerca de $1421^{27}$.

7 - A fundação da igreja paroquial de Santiago de Coimbra,junto da Porta da Almedina coimbrã, processou-se bastante antes de Junho de 1137. Por essa época, o Mosteiro de Santa Cruz de Coimbra procedeu à

${ }^{25}$ Vide Carl ERdmann, O Papado e Portugal..., pp.5 e segs.; Avelino Jesus da COSTA e Maria Alegria MARQUES, "Introdução", in Bulário Português - Inocêncio III (1198-1216), Coimbra, INIC, 1989, pp. XV-XVII, 80-95; Maria João BRANCO, "Portugal no reino de Leon. Etapas de uma Relação (866-1179)", in El Reino de León en la Alta Edad Media. IV. La Monarquía (1109-1230), León, Centro de Estudios e Investigación, 1993, pp.537-623.

${ }^{26}$ Cf. Carl ERDMANN, op. cit., pp.5-34. Um mapa desta distribuição pode encontrar-se na obra de Peter LINEHAN, La Iglesia Española y el Papado en el S. XIII, Salamanca, Universidad Pontifícia, 1975, p. LVII. (Vide reprodução).

${ }^{27}$ F. Félix LOPES, "Franciscanos", in Verbo - Enciclopédia Luso-Brasileira de Cultura, Vol. 8, Lisboa, Verbo, 1969, cols.1546-1555. 
demarcação da sua freguesia urbana que confinava com os termos das paróquias de $\mathrm{St}^{\mathrm{a}}$ Justa e de Santiago, estando presentes ao acto alguns fiéis paroquianos de Santiago.

A igreja de Santiago gozava duma certa importância contando entre os seus fregueses gente de posses. Lembremos o caso do rico Godesteu que, em Maio de 1147, lhe testou um morabitino e outro tanto para a confraria nela sediada ${ }^{28}$. Que Santiago de Coimbra era uma das paróquias mais rentáveis da cidade, significando isso maiores tributações dizimistas sobre os respectivos paroquianos, pode observar-se facilmente pelo censual de 1321 , em que surge a render 650 libras, enquanto a sua vizinha de $\mathrm{St}^{\mathrm{a}}$ Justa ascendia às 800 libras. Indicadores deveras significativos se retivermos que as restantes paroquiais da cidade se ficavam por valores bem mais baixos, rondando os $2 / 3$ ou mesmo $1 / 3$ do valor apontado para a igreja colegial de Santiago ${ }^{29}$.

$\mathrm{Na}$ verdade, Santiago de Coimbra deve remontar ainda a finais do século XI ou inícios da centúria seguinte, não datando do fim do século XII, como vem sendo indicado por alguns autores. Nessa fundação devem ter estado directa ou indirectamente envolvidos arquidiocesanos compostelanos uma vez que o arcebispo jacobeu reclamará direitos eclesiais de padroado nesta igreja paroquial em inícios de 1180 , que afirmava

${ }^{28}$ Livro Santo de Santa Cruz (ed. Leontina VENTURA e Ana Santiago FARIA), Coimbra, INIC, 1990, pp. 107 e 155.

${ }^{29}$ A saber: S. João de Almedina $=300$ libras; S. Salvador $=250$ lbr.; S. Cristóvão = 480 lbr.; S. Bartolomeu = 540 lbr.; S. Pedro = 300 lbr.. Existem diferentes fontes com este censo de 1321, nomeadamente nos cartórios do cabido da Sé de Coimbra e do Mosteiro de Santa Cruz de Coimbra depositados na Torre do Tombo / Arquivos Nacionais, em Lisboa. Uma das lições encontra-se no Censual da Diocese de Coimbra (Cópia de 1535), de que há reprodução fotográfica no Instituto de Paleografia e Diplomática da Faculdade de Letras de Coimbra (Cx. 231, fls. 13-14v ${ }^{\circ}$. $\mathrm{O}$ "Catálogo de Todas as Igrejas... de 1320 e 1321" foi publicado por Fortunato de ALMEIDA, a partir duma versão de 1746, na História da Igreja em Portugal, (Nova edição por Damião PERES), Porto, Civilização, 1971, Vol. IV, pp.90-144, maxime 122-127. 


\section{Saul António Gomes}

imemoriais, posto que contestados pelo prelado de Coimbra. Importará reflectir por ora que devemos estar perante uma situação histórica mais contextual.

Efectivamente, parece-nos sugestivo avançar com a hipótese da fundação de Santiago de Coimbra, confinante com a mais importante via de recepção de viajantes e peregrinos que demandavam a cidade, circundante à Porta de Almedina, se integrar num amplo fenómeno de expansão pastoral protagonizado pela Ordem de Cluny em toda a Península Ibérica sob domínio cristão. Isto é tanto mais significativo quanto o facto de ter sido justamente a esta Ordem que foi doada, em 1102, a administração eclesial da paróquia coimbrã de $\mathrm{St}^{\mathrm{a}}$ Justa, imediata vizinha da de Santiago ${ }^{30}$.

O esforço protagonizado pelos cluniacenses pela reforma dos costumes e práticas litúrgico-religiosas hipano-moçárabes (que em Coimbra encontravam um fortíssimo baluarte social de apoio) em favor duma uniformidade romano-gregoriana deve ter também integrado, nas suas práticas actuantes, uma postura favorável à generalização do culto jacobeu. Generalização que pressupunha de algum modo o seu controle a fim de nele incutir uma matriz formalizante de carácter puramente gregoriano.

Antes da ascensão ao poder de D. Afonso Henriques, alguns dos antístites compostelanos participavam na vida eclesial coimbrã. Exemplo disso colhe-se no facto do prelado de Santiago de Compostela, Dalmaciano, bem como do cónego Diogo Gelmires, "ecclesiesancti lacobi canonicus", aparecerem entre os confirmantes da doação do Mosteiro da Vacariça à Sé de Coimbra, em 13 de Novembro de $1093^{31}$.

${ }^{30}$ Vd. Avelino de Jesus da Costa, "A Ordem de Cluny e Portugal", Cenáculo, 3, 1948, pp. 185-220.

${ }^{31}$ Livro Preto da Sé de Coimbra, fls. 40-41 (ed. Torquato Sousa SOARES, A. Jesus da COSTA, et al.), Arq. Univ. Coimbra, Vol. I, Coimbra, 1977, pp.121-123; Fr. António 
Mais tarde, por finais da década de 1130, encontraremos cónegos regrantes de Santa Cruz de Coimbra caminhando para a cidade jacobeia a fim de ali copiarem manuscritos que entendiam necessários à sua biblioteca $a^{32}$. O interesse dos prelados deste mosteiro pela vida espiritual da Galiza manifestar-se-á, ainda, por 1172, ano em que vemos, entre os peticionários que subscreveram a o pedido da beatificação de S. Rosendo de Celanova, justamente, o nome de D. João Teotónio, Prior-mor da Canónica ${ }^{33}$.

Os documentos registam a presença de outros diocesanos compostolenses em terras do Mondego. Um deles era, justamente, João Fernandes, porcionário de Santiago de Compostela, o qual, recolhido ao claustro de Santa Cruz de Coimbra, lavrou alguns diplomas para a chancelaria da infanta D. Teresa, nas décadas de 1220 e 1230 , alusivos ao cenóbio cisterciense de Santa Maria de Celas de Guimarães, cuja edificação então se processava nos arredores da cidade mondeguina ${ }^{34}$.

BRANDÃO, Monarquia Lusitana, III, Lisboa, 4" ed. fac-similada, I.N.-C.M., 1974, Livro 8, Cap $^{\circ}$ 7, p. 21, col. 2; João Pedro RIBEIRO, Dissertações Chronologicas e Criticas sobre a Historia e Jurisprudencia ecclesiastica e Civil de Portugal, Lisboa, 1810, Vol. III, Parte I, p. 30.

${ }^{32}$ Lemos, de facto, a Vida de D. Teotónio que este Prior-mor de Santa cruz mandou cónegos a Compostela e a S. Rufo de Avinhão, a fim de recolherem, nesses locais, informações quanto aos regimes de governo próprios de canónicas regrantes de Santo Agostinho. Vd. Hagiografia de Santa Cruz de Coimbra. Vida de D. Telo, Vida de D. Teotónio, Vida de Martinho de Soure, (edição crítica de Aires A. Nascimento), Lisboa, Colibri, 1998, pp. 168-169.

${ }^{33}$ Ordoño de Celanova: vida y milagros de San Rosendo (cura M. C. DIAZ Y DIAZ, Maria V. Pardo GóMEZ, D. VILARIÑO PINTOS e José CARRO OTERO), La Coruña. Fundación Barrié de La Maza, 1990, pp. 278-280.

${ }^{34}$ Cf. Saul GOMES, In Limine Conscriptionis. Documentos, Chancelaria e Cultura no Mosteiro de Santa Cruz de Coimbra (Séculos XII a XIV), (dissertação de Doutoramento; policopiada), Coimbra, Faculdade de Letras, 2000, pp. 735-736. Este scriptor compostelano testemunha, ainda, uma doação de certos bens rústicos em Figueiró do Campo (c. Soure) feita por Santa Cruz ao Mosteiro de Celas, em Março de 1234. Vd. Maria Helena da Cruz COELHO, o Baixo Mondego nos Finais da Idade Média. (Estudo de História Rural), Coimbra, Faculdade de Letras, 1983, Vol. II, doc. 8, pp. 739-740. 


\section{Saul António Gomes}

A desistência, por parte do bispo compostelano, de direitos sobre igreja paroquial de Santiago de Coimbra, foi lavradajustamente nesta cidade, em composição com D. Martinho, bispo conimbricense, datada de 19 de Março de 1183, estando presentes, diante de D. Afonso Henriques, D. Pedro III, arcebispo compostolense, bem como o arcediago, o mestre-escola e ainda um "iudex" de Santiago de Compostela.

Por essa composição, o Arcebispo de Compostela reconhecia à Sé de Coimbra, na igreja paroquial de Santiago, o direito à "tertiam decimarum et ius diocesanum (...) cum omnibus pertinentis suis, preter ius diocesanum, iure fundi et patronus seu proprietatis ${ }^{135}$.

$\boldsymbol{A}$ presença de elementos da clerezia compostelana nas terras coimbrãs seria eventualmente frequente, sobretudo porque se tornava necessário à mesa arcebispal de Compostela a ela enviar, com certa regularidade, os seus delegados e procuradores a fim de zelarem pelos interesses senhoriais e de algum domínio espiritual que exercia na diocese mondeguina ${ }^{36}$.

Ao metropolita compostelano interessavam ainda os rendimentos proporcionados pelos designados" votos de Santiago", de que a diocese coimbrã não se exímia, mas sobre cuja cobrança efectiva em terras mondeguinas quase tudo ignoramos ${ }^{37}$. Por 1377, contudo, sabemos que eram colectados em Soure . $^{38}$.

${ }^{35}$ Livro Preto, doc. 7.

${ }^{36}$ Estamos mais documentados para o caso de D. Pedro Tenório, arcebispo de Toledo, cujos direitos senhorial-eclesiásticos no bispado de Coimbra foram arrolados, em 24.XI.1377, por Gonçalo Diez, seu procurador. Vide Maria Helena da Cruz COELHO, op. cit., Vol. II, doc.42, pp. 791-793.

${ }^{37}$ Avelino Jesus da COSTA, "Votos de Santiago", in Dicionário de História de Portugal (Dir. Joel Serrão), Vol. VI, s.l., Iniciativas Editorias, 1979, pp. 341-342.

${ }^{38}$ "E os vodos de Soire sabha se se forom tirados e pagados." Referência colhida no memorial dos direitos eclesiásticos que o arcebispo de Toledo e bispo de Coimbra trazia arrendados na diocese coimbrã, em 24.XI. 1377 (Maria H. Cruz COELHO, op. cit., Vol. II, p.792). 
O testemunho histórico mais conhecido dum relacionamento institucional entre os prelados destas duas dioceses respeita à já citada composição sobre a administração da igreja de Santiago de Coimbra. Efectivamente, em 13 de Março de 1183, definiu-se a questão do padroado sobre esta igreja paroquial entregando-se o direito deste ao bispo colimbriense, então D. Martinho, juntamente com a terça dos dízimos paroquiais, renunciando o arcebispo de Compostela, D. Pedro III, a quaisquer direitos que pudesse deter sob a respectiva administração ${ }^{39}$.

8 - As igrejas dedicadas a Santiago multiplicaram-se na diocese coimbrã particularmente, cremos, no contexto da Reconquista ao longo do século XII. Não estranha, assim, que encontremos este orago atribuído a bom número de paróquias mondeguinas logo nos tempos medievais e ainda na actualidade ${ }^{40}$.

39 " (...) Adueniens colinbriam domnus petrus compostellanus archiepiscopus. iijus, cum domno martini colimbriensi antistite. de assensu eorum qui de utraque ecclesia aderant clericorum coram inclito portugalensium rege. A(lfonso). cognita et auditis consuetudinibus antiquis talem inijt compositionem. uidelicet ut cathedrali prescripta colimbriense ecclesia tertiam decimarum et ius diocesanum in prenotata ecclesia sanctj lacobi de coljmbria cum omnibus pertinentis suis preter ius diocesanum iure fundi et patronatus seu proprietatis sine aliqua inquietatione perpetuo habeat, et possideat (...). (ANT T - Livro Preto da Sé de Coimbra, fls. 5v -6; Pub., Livro I, doc. VII, pp. 14-15). Vide Miguel Ribeiro de VASCONCELOS, "Noticia Historica do Mosteiro da Vacariça, Doado á Sé de Coimbra em 1094, e da Serie Chronologica dos Bispos d'Esta Cidade desde 1064, em Que Foi Tomada aos Mouros - II" Parte", in Historia e Memorias da Academia Real das Sciencias de Lisboa - Nova Serie, 2" Classe, Tomo I, Parte II, Lisboa, 1905, pp.283-240; doc. 22, pp.277-278; António VASCONCELOS, A Sé-Velha de Coimbra, I, Coimbra, Arquivo da Universidade, 1993, pp. 104-105.

${ }^{40}$ Posto que não referidas no censo de $\mathbf{1 3 2 0} / \mathbf{2 1}$, ou por ainda não existirem, ou por se situarem em zonas coutadas lançadas só globalmente naquele rol. Entre essas, citemos Santiago de Figueiró do Campo (c. Soure), Santiago da Guarda (c. Ansião), Santiago do Pinheiro (c. Coja), Santiago de Rio de Vide (c. Semide). Veja-se António Luiz Sousa Henriques SÊCCO, Mappa do Districto Administrativo de Coimbra, Designado Segundo Ordem Alphabetica dos Concelhos Todas as Freguezias (...), Coimbra, Imprensa da Universidade, l854,passim. 


\section{Saul António Gomes}

Antenor a 1150 era a igreja de Santiago de Almalaguês, pois neste ano estabeleceu um acordo com S. Pedro de Coimbra sobre o recebimento dos dízimos e mais direitos paroquiais ${ }^{41}$.

Em 1320/1321, a diocese coimbrã contava entre as suas igrejas paroquiais algumas dedicadas a Santiago. Nesse momento, além da igreja jacobeia da cidade, era na periferia urbana que se encontravam algumas das paroquiais mais rentáveis dedicadas a este orago. Inserida no arcediagado de Vouga, podemos indicar as igrejas de Santiago de Souselas (100 libras), antes referida, bem como a de Santiago da Moita (c. Anadia). Além destas, este arcediagado englobava ainda as paroquiais de Santiago de Creixomil [Trouxemil] (25 libras), Santiago de Eiras (100 libras), estas relativamente próximas da capital do bispado, e, mais distantes, Santiago de Vagos (160 libras) e Santiago de Codal (50 libras) (freg. Macieira do Cambra, c. Vale de Cambra).

No arcediagado de Penela, refere-se a já mencionada paroquial de Santiago de Almalaguês (45 libras).

Já no arcediagado de Seia encontramos um número mais significativo, citando-se, para aqueles anos, as igrejas de Santiago de Travanca de PaiPedrinho (50 libras) (c. Penacova), Santiago da Várzea (100 libras) (freg. Santiago de Meruge, c. Seia), Santiago dos Juncais (15 libras) (c. Celorico da Beira) e Santiago de Motinho (10 libras (?)) ( c. Arganil (?)).

Mosteiros havia que incluíam no seu património e direitos de padroado rendas dalgumas destas igrejas. Principalmente os cistercienses, casos de Lorvão que detinha Santiago de Souselas, e de Celas de Guimarães, de Coimbra, com metade de Santiago de Eiras. O fenómeno atingia também o mosteiro de Santa Cruz de Coimbra, como veremos de seguida.

"Rui de AZEVEDO, "Período de formação territorial: expansão pela conquista e sua consolidação pelo povoamento. As terras doadas. Agentes colonizadores", História da Expansão Portuguesa no Mundo (Dir. António BAIÃO, Hernâni CIDADE e Manuel MÚRIAS), Vol. I, Lisboa, Ática, 1937, p.30. 
Mas para além das igrejas citadas para 1320/21, seria necessário completar o quadro com igrejas e ermidas não citadas neste censo por pertencerem a territórios isentos ou de administração religiosa regular. Lembro o caso do Mosteiro de Santa Cruz de Coimbra, padroeiro, a título de exemplo, das paroquiais de Santiago de Leiria, Santiago de Litém (c. Pombal), Santiago de Soure e Santiago do Louriçal. Testemunhos bastante reveladores da importância que esta canónica coimbrã atribuía ao culto jacobeu nas áreas da suajurisdição eclesial ${ }^{42} \ldots$

Verificam-se algumas assimetrias a nível dos rendimentos das igrejas jacobeias apontadas na diocese de Coimbra. As mais rentáveis, no entanto, situavam-se em povoações de itinerário mais favorável aos romeiros que demandavam terras galegas. Itinerários seguramente mais importantes e movimentados, posto que não os únicos, sobretudo numa época como a Idade Média onde a deslocação pedonal não conhecia fronteiras ou caminhos obrigatórios.

Os exemplos antes citados indiciam que as paroquiais jacobeias mais rentáveis se erguiam nos "subúrbios" ${ }^{43}$, nos eixos anelares dos centros urbanos, (Coimbra, Leiria, Seia), não disfarçando as inegáveis estruturas sociais urbanas de apoio e manutenção aos circuitos de peregrinação

${ }^{42}$ Os próprios manuscritos litúrgicos crúzios guardam memória da bênção dos peregrinos jacobeus que passavam por Coimbra durante a sua viagem para Compostela. Veja-se Pedro Romano ROCHA, "El Peregrino a Santiago y la Oracion de la Iglesia", Santiago, Camino de Europa, Culto y Cultura en la Peregrinación a Compostela, Compostela, Xunta de Galicia, 1993, pp. 15-35, maxime 21 e 26. (Segundo este Autor, lê-se, efectivamente, num Pontifical proveniente daquele Mosteiro, da segunda metade do século XII (B.P.M.Porto, Ms. 353 ): "Accipe sportam, Signum peregrinationis tuae, ut per viam mandatorum Dei currens, angelus Domini bonus comitetur tecum, et bene disponat itinera tua, in nomine Patris et Filii et Spiritus Sancti. Amen. (...) Accipe baculum consolationis Dei, ut possis incedere per viam sapientiae, et per viam iustitiae revertaris ad propria in domum tuam. In nomine Patris et Filii et Spiritus Sancti. Amen ").

" "In suburbio colimbriense" situavam-se, a título de exemplo, por 1063, as "uillae" de Vilela, Travaçô, S. Lourenço do Bairro, Trouxemil e S. Martinho [do Bispo (?)]. (Livro Preto, Vol. I, doc. XIII, p.20). 


\section{Saul António Gomes}

compostelana. Bem poderemos escrever, de facto, no seguimento de outros autores, que o fenómeno do(s) caminho(s)jacobeus está irmanado com o surto e expansão dos espaços urbanos ${ }^{44}$.

9 - Devemos referir-nos ao caso do bispo de Coimbra, D. Egas Fafes (1247-1268), eleito e confirmado como arcebispo de Compostela em 1268. O seu falecimento em 16 de Abril desse ano, em Montpellier, "Tempus adimplevit, resolutus morte quievit", como referia um dos versos antigos do seu epigrama fúnebre - quando de Viterbo, onde estanciava a Cúria Pontifícia, se dirigia para tomar posse da sua novel arquidiocese, impediria esse acontecimento. O cadáver do prelado viria a receber condigna sepultura, em túmulo com estátuajacente, no interior da igreja catedralicia coimbrã ${ }^{45}$.

No seu testamento, intitulando-se "Egeas Dei gratia Compostellanus archiepiscopus" elegia "sepulturam nostram in ecclesia Colimbriensi ad quam primo Dominus nos uocauit, et mandamus corpus nostrum sepelire in sepulchro iam nobis ibidem fabricato iuxta altare beate Clare

" Vd. Carlos Alberto Ferreira de ALMEIDA, "Os caminhos e a assistência no Norte de Portugal", A Pobreza e a Assistência aos Pobres na Península Ibérica durante a Idade Média: Actas das lás Jornadas Luso-Espanholas de História Medieval, Lisboa, I. A. C, 1973, vol. I, pp. 39-57; A. H. Oliveira MARQUES, "A Circulação e a Troca de Produtos. - Vias de Comunicação", Nova História de Portugal. Vol. III, Portugal em Definição de Fronteiras..., cit., pp. 487-512.

"s "Raptus ad aetheras sedes caelique choreas, /Incolas Fafeas colit hic tumulatus Egeas. / Clarus honestate, generis quoque nobilitate, / Pontificale decus sanctus vir, Justus et aequus, /Hic est acceptus; cathedram pastoris adeptus, /Metropolitanus tandem de praesule factus / Compostellanus fuit, attamen ante coactus / Tempus adimplevit, resolutus morte quievit. / In terram cessit corpus, sed ad astra recessit / Spiritus, inde quidem duplex locus extat eidem. " ( Este epitáfio foi publicado mais recentemente por Mário MARTINS," Epitáfios em Latim Rítmico", in Introdução Histórica à Vidência do Tempo e da Morte, Vol. II, Do Teatro Pós-Vicentino Até Vieira, Bernardes e Frei António das Chagas, Braga, Livraria Cruz, 1969, pp. 100-101). Vide ainda sobre este bispo, António de VASCONCELOS, A Sé-Velha de Coimbra, I, pp. 152, 310 e 476. 
uirginis". A sua pingue riqueza permitiu-lhe beneficiar com generosidade quer o cabido conimbricense, quer inúmeros familiares e apaniguados. Nada aparece referido, no entanto, como tendo sido legado à diocese compostelana ${ }^{46}$.

A sua passagem pelo sólio coimbrão não seria, aliás, esquecida facilmente, ecoando na memória dalguns dos seus cónegos e apaniguados que lhe sobreviveram durante bastante tempo. Ainda em 15.IV. 1297, o raçoeiro da Sé coimbrã o recordava no seu testamento, deixando ao cabido as suas vestimentas sacerdotais por sua alma e pela do arcebispo D. Egas $^{47}$.

10 - Os diocesanos colimbrienses praticavam com frequência a peregrinação de conteúdo religioso. Particularmente as elites sociais e religiosas, cujas deslocações a Roma ou a Jerusalém são referenciadas com alguma frequência na documentação dos séculos XI e XII.

A Jerusalém peregrinaram alguns dos bispos de Coimbra, geralmente acompanhados por séquito constituído por alguns clérigos, nomeadamente cónegos diocesanos. Lembramos as peregrinações do bispo D. Maurício Burdino (que vimos antes aparecer ligado ao corpus lendário sobre as relíquias de S. Tiago), ou mesmo a do cónego Teotónio, futuro prior e fundador de St Cruz de Coimbra, que depois de ter ido uma primeira vez a Jerusalém chega a manifestar a sua intenção de ali regressar definitivamente ${ }^{48}$. Encontramos alguns testemunhos que provam que o

${ }^{46}$ Publicado no Liber Anniversariorum Ecclesiae Cathedralis Colimbriensis (Livro das Kalendas), (ed. por Pierre DAVID e Torquato de Sousa SOARES), T. I, Coimbra, Universidade, 1947, pp. 199-204.

"7 ANTT - Sé de Coimbra, 2" Incorporação, $M^{\circ}$ 33, Doc. 1387. (Registe-se, ainda deste raçoeiro, o legado da quantia simbólica de 5 soldos a cada uma das pontes de Coimbra, Ceira e Alva de Góis, bem como 10 soldos aos eremitas de Santa Comba, cujos percurso coincide com o de itinerários jacobeus em terras coimbrãs).

« Vita Sancti Theotonii, in Portugaliae Monumenta Historica - Scriptores, Vol. I, 
Mosteiro de Santa Cruz de Coimbra chegava mesmo a emprestar dinheiro para certos peregrinos se deslocarem a Jerusalém ${ }^{49}$.

As peregrinações a Jerusalém eram efectivamente muito valorizadas e, porventura, mesmo facilitadas pela circunstancial passagem de frotas navais com destino ao Mediterrâneo, integradas ou não no movimento das cruzadas, que aproveitariam os portos marítimos ou fluviais do extenso bispado coimbrão para estanciarem. A importância destas peregrinações era de tal ordem, que as próprias Posturas Municipais de Coimbra, de 1145, determinavam, numa enunciação de um espírito cruzadístico privilegiador da luta contra os "infiéis" no território peninsular e, mais especificamente, na "estremadura " coimbrã, que "omnesqui voluerint ire Jherosolimam non habeant licenciam eundi sed in auxilio illius castelli de Leirena et tocius Extremature. Et quicumque ibi fuerit mortuus habeat talem remissionem sicuti illi qui migraverit in Jherosolimis. ${ }^{150}$.

A documentação é bastante mais discreta no que respeita às peregrinações de diocesanos conimbricenses a Santiago de Compostela. Abundam os documentos que se referem duma forma universal a peregrinos, cuja hospedagem se fazia frequentemente em institutos religiosos, particularmente regulares ${ }^{51}$.

Lisboa, 1856, p. 83-b. Cf. José MATTOSO, "O ideal de pobreza e as ordens monásticas em Portugal durante os séculos XI-XIII", Religião e Cultura na Idade Média Portuguesa, Lisboa, IN-CM, 1983, pp. 300-310.

ง' V.g., Livro Santo, fls. 73-73v ${ }^{\circ}$, doc. 102 (doação, em Abril de 1146, de Paio Adaufes ao Mosteiro de $\mathrm{St}^{\mathrm{a}}$ Cruz de Coimbra de certos bens, por o ter auxiliado com um mulo e dez morabitinos que lhe emprestou quando foi a Jerusalém); Ibidem, fls.77-77 ${ }^{\circ}$, doc. 118, p. 255 (doação feita por Aragunte Soares, em Março de 1146, ao Mosteiro Crúzio, da uilla de S. Martinho (c. Viseu), em agradecimento pelos vinte morabitinos que os Crúzios lhe emprestaram para ir a Jerusalém). Outros exemplos de peregrinações idênticas para os anos de 1150,1158,1160,1166,1167 e 1169 são referenciados por J. MATTOSO, Op. cit., p.309, nota 47.

so Livro Preto, fl.222; pub., vol. III, doc. 576, p. 263.

${ }^{s 1}$ Maria Helena da Cruz COELHO, "A Acção dos Particulares para com a Pobreza 
Certamente que foram inúmeros os romeiros diocesanos de Coimbra que se deslocaram ao santuário jacobeu. Mas não podemos apresentar elementos quantitativos neste domínio. Lembremos a preciosa descrição em documento tabeliónico lavrado na Guimarães de Quatrocentos onde se descreve um Pero Martins "natural que dizia que era d'acerca da villa de Leirea [então na diocese coimbrã] reciiuto e apostado come homem que qer andar caminho com sombreiro na cabeça e huum bordam na mão e huã cabaciinha pequena na ciinta", que receberia esmola da Colegiada de $\mathrm{St}^{\mathrm{a}}$ Maria deste burgo minhoto ${ }^{52}$.

Mais célebre peregrina foi $D$. Isabel de Aragão (t 1336), modernamente consagrada santa padroeira de Coimbra, que por duas vezes se deslocou ao Santuário galego prestando memorável homenagem a Santiago $0^{53}$.

11 - Na documentação medieval do cartório do Cabido catedralício de Coimbra, apraz-nos registar a existência, nalguns testamentos, de referências à Galiza medieval. Lembro o exemplo do testamento do abastado cónego João Gomes, datado de 27 de Outubro de 1322, que, entre outras actividades, acumulava a de prestamista. Um dos seus

nos Séculos XI e XII", in A Pobreza e a Assistência aos Pobres na Península Ibérica

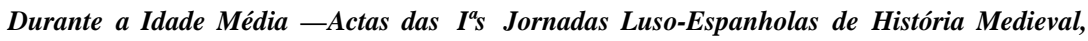
Tomo I, Lisboa, 1973, pp.231-257 (nova publicação em Homens, Espaços e Poderes. Séculos XI-XVI. I. Notas do Viver Social, Lisboa, Livros Horizonte, 1990, pp. 78-104).

${ }^{2}$ Citado por José MARQUeS, $O$ Culto de S. Tiago..., p. 24, nota 40. Publicado por José MARQUES, " A Colegiada de Guimarães no priorado de D. Afonso Gomes de Lemos (1449-1487)", in Actas do Congresso Histórico de Guimarães e a sua Colegiada, Vol. II, Guimarães, 1981, p. 254.

s" Humberto Baquero MORENO, Alcina Manuela de Oliveira MARTINS, "Figuras de la Realeza Portuguesa en Peregrinación a Santiago",Santiago, Camino de Europa Culto y Cultura en la Peregrinación a Compostela, cit., pp. 99-119; José MARQUES, $O$ Culto de S. Tiago no Norte de Portugal, sep. de Lusitania Sacra, 2' Série, 4 (1992), pp. 24-31. 


\section{Saul António Gomes}

credores devia-lhe justamente cem "Riphas gallecas", quantia decerto considerável no conjunto de dezasseis empréstimos que concedera em moeda, não se contabilizando os empréstimos em géneros. Só em dinheiro, este cónego regista no seu testamento préstamos que ascendiam a 412 libras, 114 soldos, 1 marco de prata além das mencionadas 100 libras galegas ${ }^{54}$.

É curioso citar aqui, igualmente, o caso de João de Lourosa, o qual era cónego nas dioceses de Coimbra, Porto e Palencia, além de prior de Penacova. Entre as respectivas verbas testamentárias legou, ao Hospital de $\mathrm{St}^{\circ}$ Antolin de Palencia, 100 morabitinos brancos "de ssa prebenda d'ala pera meterem em rroupa pera os proves." Não se tratando de um prebendado em terras de administração compostelana, contudo, não deixava de possuir um saltério "coberto de couro de bezerro. que me fez Lourenço steuez capeiam de Santiago" [de Coimbra] - testemunho que alude a um provável scriptorium instalado por essa altura na igreja colegial coimbrã desse orago ${ }^{55}$.

12 - Sobre metropolitanos de Compostela, as notícias colhidas nos cadernos de matrículas de ordens sacras da Sé coimbrã são algo mais abundantes. Conhecemos cadernos para os anos de 1400 (64 ordenações). 1409/11 (419 ordenações), 1419 (42 ordenações), 1420 (46 ordenações), 1427 (41 ordenações), 1431 (140 ordenações), 1435 (91 ordenações), 1470/71 (265 ordenações) e 1472 (149 ordenações) ${ }^{\text {s6 }}$.

${ }^{s 4}$ ANTT - Sé de Coimbra, $2^{a}$ Incorp., $\mathbf{M}^{\circ} 3, \mathbf{N}^{\circ} 15$.

${ }^{s s}$ A NT T - Sé de Coimbra, $2^{a}$ Incorp., $M^{\circ} 32$, Doc. 1348. (Vide apêndice documental).

${ }^{s 6}$ Para tudo isto remetemos para Saul GOMES, "Diocesanos bracarenses de Quatrocentos nas matrículas de ordens sacras da Sé de Coimbra", in IX Centenário da Dedicação da Sé de Braga. Congresso Internacional, Actas, Vol. II / 1, A Catedral de Braga na História e na Arte (Séculos XII-XIX), Braga, Univ. Católica Portuguesa e Cabido Metropolitano e Primacial de Braga, 1990. pp. 557-587. 
Neste contexto, contudo, encontramos diocesanos compostelanos apenas para os anos de 1409/1411, 1419, 1470 e 1472. Aparecem-nos representantes das dioceses de Compostela, Tui, Burgos, Orense, Zamora, Placencia, Salamanca e Badajoz. Surge ainda um clérigo de León, diocese não sujeita à de Santiago de Compostela. Não cumpre citar, aqui, os casos bem mais numerosos de clérigos pertencentes às dioceses de Lamego, Guarda, Lisboa e Évora, posto que, na medievalidade, sujeitos largo período à catedral metropolítica iriense.

A percentagem dos clérigos compostelenses queda-se por $1,3 \%$ do total de ordenações documentadas. Poderemos juntar a este índice mais dois elementos, um, já antes mencionado, oriundo de León e outro indicado como proveniente de "Castela" o que faria subir a percentagem para $1,44 \%$.

Números mais significativos encontram-se na diocese bracarense, como se demonstrou em recente estudo ${ }^{57}$. Razões de proximidade geográfica justificam esta diferença de acorrência de clérigos galaico-compostelanos às ordenações sacras de Braga ou de Coimbra. A distância era, efectivamente, um factor determinante, mas não o mais decisivo, ou sequer impeditivo, como se comprova, no processo. Verificamos, neste sentido, que todos os ordenandos oriundos dessas paragens tinham de fazer prova da sua residência na diocese coimbrã pelo menos por um período de dez anos ou mais.

Nas ordenações de 1409/11, este preceito é claramente referenciado, aplicando-se-lhe o conceito de "compatriota". Vocábulo que, como se prova, se escrevia não por critérios de política de Estado mas somente por uma classificação axiológica de âmbito regional ou local.

${ }^{57}$ José MARQUES, "Relações Galaico-Bracarenses, no século XV, segundo as Matrículas de Ordens do Arquivo Distrital de Braga", Relações Entre Portugal e Castela nos Finais da Idade Média, Lisboa, Fund. Calouste Gulbenkian e JNICT, 1994, pp. 325-347. 


\section{Saul António Gomes}

Verifica-se ainda que os ordenandos compostelanos foram promovidos quer a título do seu património pessoal (Lourenço Eanes e Fernando Peres, ambos diocesanos de Santiago de Compostela, em 26 de Junho de 1409; Pedro Gil, paroquiano de S. Pedro de Gaiate, diocese de Tui, em 11 de Abril de 1411), quer a título de benefícios e rações paroquiais conimbricenses (v.g., Fernando Gonçalves de Araújo, da diocese de Orense, promovido no título da igreja de $\mathrm{St}^{\mathrm{a}}$ Maria de Tábua em 15 de Agosto de 1409), ou mesmo sem menção expressa deste título.

Por vezes, é referenciada a atestação da idoneidade do candidato lavrado pela autoridade diocesana respectiva. Encontramos mais documentada esta faceta nos clérigos oriundos de Tui (v.g., Pedro Gil, "per licteris Gomecii archidiaconi de Cerueyra vicarii generallis Reuerendi patris domni Antonii episcopi Tudensi", em 11.IV. 1411; Gil Esteves, Martinho Eanes e Rodrigo Martins "de licenciam Gunsalui Martini canonici ac bicarii in dicta ecclesia Tudensis diocesis quasi sede uacante", em 23.IX.1419).

Esta atestação por parte dum superior era necessária e obrigatória para os clérigos regulares. Tal verifica-se efectivamente nos dois casos encontrados (v.g., Fr. Afonso de Burgos, trinitário, e Fr. António de Castro, franciscano de Salamanca, de 1470 e 1472, respectivamente).

Entre os casos referenciados, doze respeitaram à recepção de ordens menores e seis à ordem do presbiterado ${ }^{58}$.

13 - Os elementos históricos antes expostos referem-se a um processo social caracterizado pelas deslocações de agentes compostelanos em territórios dajurisdição episcopal coimbrã. O seu volume não parece ser muito significativo e deve integrar-se num processo histórico migracional

${ }^{s 8}$ Veja-se o apêndice documental onde se apresentam as fontes compulsadas para esta questão. 


\section{Coimbra e Santiago de Compostela}

que desde cedo caracterizou as populações galaico-minhotas que procuravam nos territórios meridionais novos meios de sobrevivência ou mesmo de enriquecimento.

As matrículas de ordens sacras conimbricenses atestam a presença de um número qualitativamente interessante, em termo de demografia medieval, de "compatriotas" de origem galega, isto é, de clérigos que procuraram fixar-se no território mondeguino, aqui adquirindo um estatuto social que lhes permitiria mesmo candidatarem-se com êxito aos benefícios e prebendas paroquiais e colegiais da diocese.

Interessaria, decerto, conhecer se se processou o fenómeno inverso, isto é, se os conimbricenses procuravam o território galego para fixação e evolução profissional. Só uma pesquisajunto de fontes arquivísticas do mesmo género permitirá responder com segurança a esta questão.

Mas não nos estranharia muito que, no futuro, apenas conseguíssemos confirmar o antigo e estrutural processo migracional das populações do setentrião hispânico para os territórios do sul, menos povoados e, eventualmente, com maiores oportunidades de trabalho e de enriquecimento.

Santiago de Compostela, contudo, permaneceria, ao longo de toda a Idade Média e mesmo nos séculos posteriores, um pólo cultural (e cultual...) referencial e identificador da Christianitas, mantendo-se como espaço e pretexto de romagem e de devoção para os diocesanos do Bispado de Coimbra, tanto quanto factor de enriquecimento global para esta cidade portuguesa, pelas inter-relações que continuaria a suscitar nos planos religioso, eclesiástico-institucional, social e, também, económico. 


\section{APÊNDICE DOCUMENTAL ${ }^{s 9}$}

Doc. 1

1322, Junho, 18, Coimbra - Testamento de João Rodrigues, cónego nas dioceses de Coimbra, Porto e Palencia.

A] ANTT - Sé de Coimbra, 2 incorp., M $^{\circ} 32$, Doc. 1348.

Obs.: publica-se apenas parcialmente.

En nome de Deus amen.

Conhoscam quantos este strumento de testamento virem que eu Joham de Lourossa Coonigo de Coinbra do Porto de Palença e priol da Eygreja de Pena Cova com todo meu ssisso e entendimento cumprido que me Deus deu e em mha vida e em mha saude temente o dia da mha morte e o estreito dia do juizo nom sabendo quando avia a sseer a que todos avemos $d$ ir aperelhados pera rreceber galardam cada huum do que fez, ffaço meu testamento em esta maneira

Primeiramente mando a mha alma a Deus e a Virgem Sancta Maria e a toda a Corte do çeo que mim ajam parte neela.

E mando meu Corpo seer soterrado na Eygreja de Coinbra hu esculher sa sepultura. E peço por messura ao Cabidoo que me den huã sepultura em aquel lugar hu a avia outorgada ao priol de San Nicola.

E mando lhis dar quareenta .libras, que sayan trynta dias sobre mim.

E mando lhis .vynte. libras no dia de mha sepultura.

$\S$ Item mando aos bachaleres da See .dez. libras, que me digam dez missas offiziadas e que saiam sobre mim.

$\S$ Item mando ao espital de Sant'Antol[in] de Palença .cen. morabitinos de brancos dessa prebenda dala pera meterem em rroupa pera os proves.

$\S$ Item mando toda a mha herdade de Lourossa cassas vinhas arvores a Vaasco e a Rodrigo filhos de Sancha salvo aquela herdade e cassas que forom de Vicente Perez per que quero que se mantenha huum capeiam com outra herdade de Marta Dominguez que ha de ficar a mim [...]. E se pela ventura [...] nom avondar

s9 Principais critérios de transcrição: a) respeito pelo texto original; b) desenvolvimento de abreviaturas sem assinalar letras restituídas; c) normalização de maiúsculas e minúsculas consoante se trate de nomes próprios ou comuns; d) normalização das letras u e v, i e j. consoante se trata de vogais ou consoantes. 
pera sse manteer o Capelam mando que os meus testamenteiros dem trezentas. libras que conpre en elas herdade [...] per sse manteer a capela. E quero que esta Capela que se mantenha per Pero Martiinz meu subrinho filho de Marinha Martyz mha irmãa enquanto el viver.

E depos sa morte mando que se mantenha per Vaasco meu criado [...] E se o hi nom ouver [...] que se mantenha per Rodrigo seu irmão [..] e ssy vaa per soçessom que sse mantenha pelos clerigos do meu linhagem que sejam clerigos de boons costumes. E toda a herdade que ey en Sea e en seu termho [...].

$\S$ Item mando todo meu olival de Pena Cova [...] E mando que o Cabidoo de Coimbra aja cinque libras em cada huum anno per aquel olival de Pena Cova por dia de meu aniversario.

E quanto aos enplazamentos que tenho em Galizes e Vila Chãa, o de Galizes mando a Vaasco, e o de Vila Chãa a Rodrigo e que pagem a renda ao Moesteiro de San Jorgi [...].

$\S$ Item mando a Vaasco Martinz meu irmão cen libras [...].

$\S$ Item mando a Alvaro trynta libras [...].

$\S$ Item mando a Lourenco Viçente quareenta libras por serviço que me fez.

$\S$ Item mando que os tolham a cada huum come os merecer.

$\S$ Item mando que dem a Maria criada de Stevam Dominguez Coonigo de Guarda o que for achado que eu rrecebi de Tuitelhom e do Homem Calvo que tem a vinha do Geestal e creo que sum quareenta e cinque libras.

\section{[...]}

$\S$ Item mando aos meus testamenteiros que den o Sabado e os trynta dias. e o ano aquele que virem que sera bem por mha alma aos proves.

$\S$ Item mando aos frades de San Francisco e de Sam Domingos .cinque. cinque. libras. pera pitança e que me venham fazer honrra a mha sepultura.

$\S$ Item mando aos frades de Sam Jorgi .dez. libras pera pitança.

$\S$ Item mando a cada huã das egreias de Coinbra vynte. vynte. soldos que venham a mha sepultura e tragam as cluzes.

$\S$ Item mando a egreja de Lourossa polo bem que dela rrecebi huum calez. de plata duum marco.

$\S$ Item mando a Migeel Martinz clerigo vynte e cinque libras por serviço que me fez.

$\S$ Item mando a Stevam Perez vynte e cinque libras.

$\S$ Item mando aa eygreja de Pena Cova hum salteiro coberto de couro de bezerro que me fez Lourenço Stevez capelam de Santiago.

$\S$ Item digo que tenho huum salteiro de Francisco Perez por nove libras e se 
as der aalem das que deve dem lho.

$\S$ Item comprei outro salteiro d'Affonso Bertolameu quero que seja pera a capela de Lourossa se sse ouver a manter e mando que o entregem a Pero meu subrinho que o tenha pera essa Capela.

$\S$ Item mando aas donas de Sancta Ana tres libras.

$\S$ Item mando aas donas de San Jorgi vynte soldos.

$\S$ Item mando as confrarias de Sancta Maria e de San Lourenço vynte. vynte soldos.

$\S$ Item mando aos Gafos de Coinbra .dez. soldos.

$\S$ Item mando a Gonçalo meu subrinho o Gielio que tem seu irmão e o Sexto livro que tem Steuam Perez.

E mando que Pedro guarde todos os livros da Gramatica que lhi enprestou o abade de Tresmires e que leãm seus subrrinhos per eles. E mando que lhos nom de ata que lhe de o Gonfedro que tem o qual lhi enprestou Antoninho Stevez.

$\S$ Item mando que quitem a Martim Carragossela quinze libras se der boom conto daquelo que de mim rrecebeu e de que ouve de veer do meu.

E mando que todolos testamentos que ei fectos ante deste que nom valham mais $[\ldots]$.

E faço eixecutores deste meu testamento dom Vaasco Martyz bispo do Porto e Affonso Perez Britacampos e Affonso Perez Branco e Affonso Annes abade de San Miguel de Veeyri que eles façam por mim e por a mha alma assi come Deus destrenga que faça por as suas quando deste mundo sairem [...].

Fecto foy en Coinbra dez e oyto dias de Juynho da Era de mil e trezentos e sateenta anos. Testemunhas [...] Stevam Perez clerigo de Joham de Lousada, Migeel Martinz vigairo da Mereça. Gonçalo Stevez scolar. Pero Martyz de Varazim seu subrinho. Pero Dominguez de Lorvão. Martim Bravo filho d'Estevam da Marmelheira. Martim Affonso criado d'Afonsso Annes e outros [...]. Tabaliam Martim Gonçalviz [...].

\section{Doc. 2}

1409-1411 - Registos das ordenações sacras realizadas na diocese conimbricense relativas a clérigos oriundos de Santiago de Compostela e de Tui.

ANTT - Cabido da Sé de Coimbra, 2 $2^{\mathrm{a}}$ incorp. $\mathrm{M}^{\circ} 100, \mathrm{~N}^{\circ} 4831 \mathrm{a}$. 
Item post hec Colimbrie in camera domini Egidii Episcopi Colimbriensi videlicet die vigesima sexta mensis Junii Anno a natiuitate. Domini millesimo quadrigentesimo nono, dictus dominus Episcopus promouit istos tres que secuntur ad primam et ad omnes alios minores ordines.

$[\ldots]$

Item Laurencium Johanis filium Lopi Johanis et eius vxoris Tarasie Gunsalui habitantium in diocesis Compostellanensis qui per decenium et ultra in nostra ${ }^{60}$ etc ${ }^{a}$ propter quod factus est compatriota etc ${ }^{a}$ promotus ad titulum suj patrimonii, ad primam clericalem tonsuram iam promotus, fuit per eundem episcopum promotus ad omnes alios minores ordines.

Item Fernandum Petri filium Fernandi Petri, et eius uxoris Orrace Johannis habitantium in diocesis Compostellanensis qui per decenium et ultra factus est compatriota etc. promotus ad titulum sui patrimonii, ad primam et ad omnes alios iiiior minores ordines.

\section{[Fl. $\left.10 v^{\circ}\right]$}

Item qui[n]tadecima die Augusti in festo Assumptionis beate Marie., ${ }^{61}$ anno Domini millesimo quadrigentesimo nono, in loco de Tauoa Colimbriensis diocesis, domnus Egidius Episcopus Colimbriensis, in sua camera de speciali gratia promouit istos septem, ad primam clericalem tonsuram et ad omnes alios .iiiior. minores ordines.

Item Fernandum Gunsalui de Araujo Auriensis diocesis, que per decenium et ultra etc ${ }^{a}$ cumquo super defectu natalium quem patitur de coniugato genitis et soluta auctoritate ordinaria per eundem episcopum extitit dispensatum, promotus ad titulum ecclesie sancte Marie de Tauoa predicte diocesis ad primam clericalem tonsuram ed ad omnes alios minores ordines.

\section{[...]}


as der aalem das que deve dem lho.

$\S$ Item comprei outro salteiro d'Affonso Bertolameu quero que seja pera a capela de Lourossa se sse ouver a manter e mando que o entregem a Pero meu subrinho que o tenha pera essa Capela.

$\S$ Item mando aas donas de Sancta Ana tres libras.

$\S$ Item mando aas donas de San Jorgi vynte soldos.

$\S$ Item mando as confrarias de Sancta Maria e de San Lourenço vynte. vynte soldos.

$\S$ Item mando aos Gafos de Coinbra .dez. soldos.

$\S$ Item mando a Gonçalo meu subrinho o Gielio que tem seu irmão e o Sexto livro que tem Steuam Perez.

E mando que Pedro guarde todos os livros da Gramatica que lhi enprestou o abade de Tresmires e que leãm seus subrrinhos per eles. E mando que lhos nom de ata que lhe de o Gonfedro que tem o qual lhi enprestou Antoninho Stevez.

$\S$ Item mando que quitem a Martim Carragossela quinze libras se der boom conto daquelo que de mim rrecebeu e de que ouve de veer do meu.

E mando que todolos testamentos que ei fectos ante deste que nom valham mais $[\ldots]$.

E faço eixecutores deste meu testamento dom Vaasco Martyz bispo do Porto e Affonso Perez Britacampos e Affonso Perez Branco e Affonso Annes abade de San Miguel de Veeyri que eles façam por mim e por a mha alma assi come Deus destrenga que faça por as suas quando deste mundo sairem [...].

Fecto foy en Coinbra dez e oyto dias de Juynho da Era de mil e trezentos e sateenta anos. Testemunhas [...] Stevam Perez clerigo de Joham de Lousada, Migeel Martinz vigairo da Mereça. Gonçalo Stevez scolar. Pero Martyz de Varazim seu subrinho. Pero Dominguez de Lorvão. Martim Bravo filho d'Estevam da Marmelheira. Martim Affonso criado d'Afonsso Annes e outros [...]. Tabaliam Martim Gonçaalviz [...].

\section{Doc. 2}

1409-1411 - Registos das ordenações sacras realizadas na diocese conimbricense relativas a clérigos oriundos de Santiago de Compostela e de Tui.

ANTT - Cabido da Se de Coimbra, $2^{\mathrm{a}}$ incorp. $\mathrm{M}^{\circ} 100, \mathrm{~N}^{\circ} 4831$ a. 
Item post hec Colimbrie in camera domini Egidii Episcopi Colimbriensi videlicet die vigesima sexta mensis Junii Anno a natiuitate. Domini millesimo quadrigentesimo nono, dictus dominus Episcopus promouit istos tres que secuntur ad primam et ad omnes alios minores ordines.

$[\ldots]$

Item Laurencium Johanis filium Lopi Johanis et eius vxoris Tarasie Gunsalui habitantium in diocesis Compostellanensis qui per decenium et ultra in nostra ${ }^{60}$ etc ${ }^{a}$ propter quod factus est compatriota etc ${ }^{a}$ promotus ad titulum suj patrimonii, ad primam clericalem tonsuram iam promotus, fuit per eundem episcopum promotus ad omnes alios minores ordines.

Item Fernandum Petri filium Fernandi Petri, et eius uxoris Orrace Johannis habitantium in diocesis Compostellanensis qui per decenium et ultra factus est compatriota etc. promotus ad titulum sui patrimonii, ad primam et ad omnes alios iiiior minores ordines.

[Fl. $10 \mathrm{v}^{\circ}$ ]

Item qui[n]tadecima die Augusti in festo Assumptionis beate Marie., ${ }^{61}$ anno Domini millesimo quadrigentesimo nono, in loco de Tauoa Colimbriensis diocesis, domnus Egidius Episcopus Colimbriensis, in sua camera de speciali gratia promouit istos septem, ad primam clericalem tonsuram et ad omnes alios .iiiior. minores ordines.

Item Fernandum Gunsalui de Araujo Auriensis diocesis, que per decenium et ultra etc ${ }^{a}$ cumquo super defectu natalium quem patitur de coniugato genitis et soluta auctoritate ordinaria per eundem episcopum extitit dispensatum, promotus ad titulum ecclesie sancte Marie de Tauoa predicte diocesis ad primam clericalem tonsuram ed ad omnes alios minores ordines.

$[\ldots]$

\footnotetext{
${ }^{60}$ Riscou: "nostra."

${ }^{61}$ Riscou: "in loco de."
} 
[Fl. 12]

In nomine Domini Amem. Nouerint vniuersi quod Sabbato Sancto. videlicet vigesimo secundo die mensis Marcii. Anno a natituitate Domini millesimo quadringentesimo decimo domnus Egidius Episcopus Colinbriensem in sua cathedrali ecclesia cellebrauit generales ordines in quibus promouit istos qui secuntur, presente me Martino Valasci notario apostolico perpetuo beneficiato in eadem ecclesie cathedrali.

Et primo istos infrascriptos ad primam clericalem tonsuram et ad omnes alios quatuor minores ordines.

$[\ldots]$

[Fl. $\left.12 \mathrm{v}^{\circ}\right]$

Item Aluarus Fernandi filius Fernandi Petri soluti et Tarasie Gunsalui solute habitantium in diocesis Tudensis qui per decenium et ultra ect ${ }^{\mathrm{a}}$, cumquo auctoritate apostolica extitit dispensatum promotus ad titulum ecclesie de Sabadini predicte diocesis ad primam et ad omnes alios iiiior ordines.

$[\ldots]$

[F1.15]

In nomine Domini amen. Nouerint vniuersi presentem matricolam inspecturi quod sabbato quatuor temporum post festum Pentecostes, videlicet, decima septima die mensis Maii anno a natituitate Eiusdem millesimo quadringentesimo decimo, domnus Egidius Alma episcopus Colinbriensem in sua cathedrali ecclesia generales ordines cellebrauit et promouit istos infrascriptos, me Martino Ualasci notario appostolico presente.

$[\ldots]$

$\left[\mathrm{F} 1.16 \mathrm{v}^{\circ}\right]$

Item Fernandum Sancii filium petri Sancii et eius uxoris Caterine Johannis habitantium in Regno Castelle qui per decenium in nostra ciuitatis et diocesis continuam vitam fecit de legitimo matrimonio procreatus, ad primam et ad omnes alios minores ordines. 


\section{$[\cdots]$}

[Fl. $22 \mathrm{v}^{\circ}$ ]

In nomine Dominj amen. Hoos qui secuntur promouit reuerendus pater domnus Egidius Alma episcopus Colimbriensem in sua ecclesia cathedrali, die Sabati Sancti videlicet vndecima die mensis Aprilis anno a natiuitate Domini millesimo quadringentesimo vndecimo celebrando ordines generales et promouit ad minores ordines.

\section{$[\ldots]$}

$\left[\mathrm{F} 1.23 \mathrm{v}^{\circ}\right]$

Item Petrum Egidii filium Roderici Garsie et eius vxoris Marine Petri de parrochia ecclesie Sancti Petri de Gayate Tudensis diocesis de legitimo matrimonio procreatus promotus ad titulum sui patrimonii per licteris Gomecii archidiaconi de Cerueryra, vicarii generalis reuerendi patris domni Antonii episcopi Tudensi, ad primam et ad omnes minores.

\section{Doc. 3}

1419 - Clérigos das dioceses de Tui e Zamora ordenados em Coimbra.

ANTT - Se de Coimbra, $2^{\circ}$ inc, $M^{\circ} 95, n^{\circ} 4630$.

[Fl. 1]

Era mjlesima iiiior quinquagesima septima die uero ${ }^{62}$ xxiij mensis Setenbris in ecclesia cathedrali sedis Colinbriensis de licencia <Aluari Pelagi, thesauraris ac bicarii > domini domni Fernandi Dei et apostolice sedis gracia episcopi eiusdem sedis Colinbriensis reuerendus domnus Lopus Dei et apostolica sedis gratia episcopus Samacensis generalles ordines celebrauit tam minores quam subdiaconatus seu adiaconatus et presbiteratus ordines sicud sequitur.

- Non sit suspectio vbi dicitur Aluari Pelagii etc ${ }^{a}$ (ass.) Johanes Andrée.

${ }^{\circ 2}$ Riscou: "pri." 
$\left[\mathrm{Fl} .1 \mathrm{v}^{\circ}\right]$

Item Egidius Stephani filius Stephani Johanis et eius uxoris Marie Johanis de parochia sancte Christine de Effifi diocesis Tudensis de licenciam Gunsalui Martini canonici ac bicarii in dicta eclesia Tudensis diocesis quasi sede uacante fuit promotus ad presbiteratus ordines.

Item Martinus filius Johannis Bincencii Tudensis de licencia Gunsalui Martini canonici ac bicarii in dicta ecclesia Tudensi quasi sede bacante fuit promotus ad presbiteratus ordines.

\section{[...]}

$\left[\mathrm{F} 1.2 \mathrm{v}^{\circ}\right]$

Item Rodericus Martini filius Martini Johannis et eius uxoris Durancie Dominici de billa de Melga§o Tudensis diocesis de licencia Gunsalui Martini canonici $^{63}$ ac bicarii generalis in dicta ecclesia Tudensi fuit promotus ad presbiteratus ordines.

$[\ldots]$

$[\mathrm{Fl} .5]$

Item Sancius Didaci filius Alfonsi Sancii de Camora r[eg]nj Castelle et eius vxoris Enes Alfonsi de legitimo matrimonio presentatus ad titulum sui patrimoni qui per decenium et ultra effectus est compatriota istius diocesis ad primam et ad omnes minores ordines fuit promotus.

(ass.) Aluarus.

Doc. 4

1470 - Clérigos compostelenses ordenados em Coimbra por D. Nuno, bispo de Tânger e Ilhas, por consentimento de D. João Galvão, prelado conimbricense.

ANTT - Se de Coimbra, $2^{\mathrm{a}}$ Incorp., $\mathrm{M}^{\circ} 94, \mathrm{~N}^{\circ} 4507$. 
[Fl.1]

Matricola dos ordenados assi de ordens meores como [e]pistola evangelho e missa per ho reverendo senhor Dom Nuno bispo de Tangere na cidade e egreja cathedral de Coimbra per licença do reverendo senhor Dom Joham Galvam ect ${ }^{a}$ bispo dessa meesma nas quatro temporas de Natal e Ciinza que foram examinadores Pero Afonso conego e vigario geeral que entam era do dicto senhor e Fernand Afonso tambem conego na dicta See ect ${ }^{a}$ Anno Domini millesimo $\mathrm{CCCC}^{\circ} 1 \mathrm{xxj}^{\circ}$.

(ass.) B(ene) Petrus Alfonsi (?) V(aleat).

$[.$.

[F1.6]

Cathedra Sancti Petri et dominica precedente.

[F1.7]

Titulo dos hordenados de missa.

Item Ruy Fernandez prior da egreia da Ventosa da menistraçam de Tuy compatriota.

[...]

Item frey Afomso de Burgos da hordem da Trindade com lecença sui maioris.

Doc. 5

1472 - Registo dos clérigos da metrópole compostelense providos em ordens sacras na diocese de Coimbra.

ANTT - Sé de Coimbra, 2 Incorp., $\mathrm{M}^{\circ} 94, \mathrm{~N}^{\circ} 4536$

[Fl.1]

Titulo das hordeens geerãees que ho honrrado in Christo padre dom Nuno bispo de Tanger celebrou na cidade de Coinbra por comisso de dom Joham 
Galvam bispo da dicta çidade aos xix dias do mes de Setembro em as quatro temporas de Santa Cruz de mill e quatrocentos e Lxxii anos a qual comissom esta de verbo inserta no cartorio da ssee em huuã matricula de outras hordeens que primeiramente celebrou.

Titulo das hordeens meores.

$[\ldots]$

Item frey Antonio de Crasto do convento de Salamanca provincia de Sanctiago.

$[\ldots]$

[Fl. $\left.2 \mathrm{v}^{\circ}\right]$

Item Joham filho de Joham Martini Preto e de Catelina Vãaz moradores em Garçiez bispado de Plazencia termo de Trogilho, freiguessia de Sanctiago.

$[\ldots]$

Item Marcos Afonso filho da Afonso Gonçallvez e de Maria Gonçallvez moradores nas Cumbres Mayores freguisia de Sam Migel bispado de Badalouçe. $[\ldots]$

Item dom Carlos filho de dom Diogo Amriquez e de dona Johana moradores nos Sanctos de Maymona na freguesia de Sancta Maria priorado de Sam Marcos de Leon tomou hordeens de prima tonssura.

\section{[...]}

[F1.7]

Titulo d ordeens de missa.

$\left[\mathrm{F} 1.7 \mathrm{v}^{\circ}\right]$

Item frey Affomso de Çamora. 